\title{
Use of local raw materials in the composition of protein-vitamin-mineral additives
}

\author{
G.A. Yarmots* \\ FSBEI HE Northern Trans-Ural SAU, Tyumen, Russia
}

\begin{abstract}
As a result of hard breeding work, people managed to achieve extremely high productivity from pigs, which entailed increased requirements for the feed quality, keeping conditions and microclimate. Pigs receive the main amount of energy from cereal grains, some energy comes from protein splitting and to a lesser extent - due to fat feed. The difference in the amount of exchange energy can reach up to $5 \mathrm{MJ}$. The lower the amount of energy in the diet, the more the animal needs to consume feed, so PVMA should be added to cereal mixtures to balance the diets by nutrients. Over the past decades, full combined fodder has become the most reliable food source for pigs. Being based on former feed mills, local enterprises are purchasing new equipment and mastering new technologies of modern combined fodder and protein-vitamin-mineral additives production for different types and age-sex groups of farm animals.
\end{abstract}

\section{Introduction}

Pigs are extremely demanding to feeding and keeping conditions. Due to their inherent biological features associated with the presence of a single-chamber stomach providing fodder digestion, energy and protein provision is the main productivity component for pigs. Therefore, the selection of feed in the diets for pigs is of paramount importance [1]. The balance of protein nutrition plays a big role for the growth and formation of meat productivity in pigs, especially in young animals. This is commonly understood as providing essential amino acids with the required amount of non-protein nitrogen for the synthesis of interchangeable amino acids.

Quite some studies are devoted to reducing the proportion of concentrates in pigs' diets with the replacement of some of them with bulk feed. Such as, in particular: tuberous roots, combined silage, herbal meal, etc. [2]. There has been a lot of positive experience of such a replacement and a considerable number of recommendations have been issued. However, the complexity of bulk feed storage and diets' feeding including these feed inhibited the introduction of such diets and the growth of pigs' productivity in the conditions of practical pig breeding. On pig farms and in animal complexes, pigs were usually fed by grain mixtures or individual grain components.

It was proved that combined pig fodder must necessarily consist of several grain components. Prolonged pigs' feeding by single grain type causes changes in the

* Corresponding author: yarmoz@mail.ru 
composition of rectum flora and reduces productivity. From the view point of feeding mechanization, giving only combined fodder to pigs is easier [3]. In the last decades, fullfledged combined fodder has become the most reliable source of nutrition for pigs and poultry [4], which is why its impact on productivity is the subject of constant scientific research.

Being based on former feed mills, local enterprises are purchasing new equipment and mastering new technologies of modern combined fodder and protein-vitamin-mineral additives production for different types and age-sex groups of farm animals.

\section{Materials and methods}

The purpose of scientific and production experiment: comparative effectiveness study of the protein-vitamin-mineral additive (PVMA) "Provimi" and PVMA "Alma" (from local components) use in diets of fattening young pigs.

For scientific and industrial experiment, 2 groups of large white breed boar pigs at the age of 4.5 months at an average live weight of $56 \mathrm{~kg}$ were selected at the pig complex on the principle of analogues. For the two-week preliminary period with the same feeding both groups showed an average daily increase of $677 \mathrm{~g}$.

During the preliminary and accounting period of the experiment, control group animals were with combined fodder with "Provimi" PVMA used at the pig complex for young pigs' fattening. Together with the diet, animals of the experimental group received PVMA "Alma" of own production from permanently available components at "Tyumen grainproducing integrated works" of the following composition (table 1).

Table 1. Composition of protein-vitamin-mineral additive "Alma"

\begin{tabular}{|l|l|}
\hline Component & \% by weight \\
\hline Soybean meal & 63.7 \\
\hline Fodder yeast & 3.6 \\
\hline Defluorinated phosphate & 5.1 \\
\hline Chalky flour & 12.1 \\
\hline Salt & 4.5 \\
\hline Premix P 52 - 1 - 18 with Acid Lac & 10.0 \\
\hline Kemzyme W & 1.0 \\
\hline Total & 100.0 \\
\hline
\end{tabular}

The experimental fodder for young pigs' fattening from 4 to 8 months of age was prepared at the enterprise from existing grain components with the inclusion of $10 \%$ of the experimental PVMA.

The following was studied in the course of the experiment: chemical composition and nutritional content of experimental combined fodder, the presence of nutrients and elements in them; the growth rate of experimental pigs' groups, fodder consumption in groups, digestibility of the diets' main nutrients; animal blood indicators; economic efficiency of pig fattening on various fodders.

Animals received full combined fodder consisting of barley - $60 \%$, wheat -20 , and oats $-10 \%$, the control group additionally received PVMA "Provimi" in the amount of $10 \%$, and the experimental group bore pigs received experimental PVMA "Alma" - 10\%.

Based on the chemical analysis of the diet's components it was found that there were no significant differences, but the experimental fodder exceeded the control in terms of the content of exchange energy - by $1,34 \%$, dry matter - by 1,35 , lysine - by 12,66 , methionine - by 7,5 , phosphorus - by 18,6 , cobalt - by 22,73 and vitamin E and B 5 by $20 \%$, at the same 
time it was inferior in iron content by $27,60 \%$, copper - by 70,00 , zinc - by 31,00 , manganese - by 8,89 and vitamin B1 - by $12,5 \%$

\section{Results and Discussion}

Bore pigs' growth intensity in the experimental groups and feed input per $1 \mathrm{~kg}$ of gain during the accounting period are shown in table 2 .

Table 2. Bore pigs' growth intensity and feed input

\begin{tabular}{|l|c|c|}
\hline \multirow{2}{*}{\multicolumn{1}{|c|}{ Indicator }} & \multicolumn{2}{c|}{ Group } \\
\cline { 2 - 3 } & control & experimental \\
\hline Average daily gain for the preliminary experimental period, g & 676 & 678 \\
\hline Average daily gain for the accounting experimental period, g & 625 & 612 \\
\hline Fodder input per 1 head per day, kg & 2.90 & 3.24 \\
\hline Total feed inputs per accounting period per 1 head, kg & 97.34 & 115.52 \\
\hline Total gain per 1 head for the accounting period, kg & 33.74 & 33.02 \\
\hline Fodder input per 1 kg of gain during the accounting period, $\mathrm{kg}$ & 2.89 & 3.50 \\
\hline
\end{tabular}

After evaluating the animal growth intensity during the experiment, it was established that due to the introduction of experimental PVMA the average daily gain decreased by 23 $\mathrm{g}$ or $2.08 \%$, with resulting gain loss of $0.72 \mathrm{~kg}$ or $2.13 \%$ over the entire period. As a result of the decrease in average daily gains, there was an extension of the accounting period, which entailed an increase in feed consumption for an even period by $18.68 \%$, by $1 \mathrm{~kg}$ of gain by $21.11 \%$.

This is due to the digestibility of the main diet nutrients in the experimental groups studied with the help of digestion experiment by the method of inert indicators with silicon oxide.

Analyzing data on digestibility, it was found that the digestibility of diet's dry matter in the experimental group was $2.0 \%$ higher, organic matter $-2.25 \%$ higher compared to the control group. Analyzing the digestibility of individual nutrients, it was found that in the experimental boar pigs group fat digestibility was higher by $18.45 \%$ (more than 1.5 times), the digestibility rate of raw fiber was higher by $4.17 \%$ and NEFS digestibility was higher by $2.3 \%$. Digestibility of the main diet nutrients in the experimental group apart from raw protein was higher.

Protein was digested by animals of the experimental group $2.91 \%$ worse than in control. This is explained by high-protein components included in the PVMA. The composition of the experimental feed contained $6,37 \%$ of soybean meal and $0.36 \%$ of hydrolysed yeast. Therefore, the quality of protein included in the control fodder is much higher due to "Provimi" PVMA, which includes animal origin feed (fish meal, meat - bone meal).

Both lack and excess of calcium in animal diets lead to a decrease in nutrient digestibility [5].

Hematological analysis shows metabolism tension and how qualitatively and correctly the feeding conditions corresponded to the needs of the animal.

Blood was taken from 3 boar pigs from each group in the final period of fattening to monitor the pig feeding fulfilment in the experimental groups, their metabolic rate and health.

The following was determined in blood and serum: hemoglobin, erythrocytes, leukocytes, total protein, protein fractions: albumins, alpha-, beta- and gamma globulins, reserve alkalinity, calcium, and phosphorus. 
The performed pigs' blood test was within the physiological norm, at the same time in animals of the experimental group the amount of hemoglobin was higher by $1.65 \%$, and the total protein content - by $0.72 \%$, which indicates better use of fodder protein.A fair trait of mineral feeding full value is reserve alkalinity. The lack of mineral elements leads to the accumulation of basic acids throughout the animal body and as a result, reserve alkalinity decreases [6].

After introducing PVMA "Alma", an increase in reserve blood alkalinity by $7.9 \%$ occured, indicating a more complete supply of animals with minerals.

In the vital activity of the animal organism, mineral elements are of great importance, but their content in hemolymph is dependent with, firstly, in relation to nutrition, secondly with physiological state $[7,8]$.

Analyzing the blood serum, it was determined that the calcium and phosphorus content in the experimental group were higher by 2.83 and $2.62 \%$, which confirms that metabolic processes were more intense.

As a result of the conducted studies, it can be concluded that the introduction of experimental PVMA “Alma" to bore pigs' diet has a positive effect on hematopoiesis and protective body properties.

Meat qualities of experimental group animals (based on the results of control slaughter) were not lower than in the control group. So, the animals of the control group showed better results than experimental group in live weight and freshly drawn carcass weight by 3.57 and $1.35 \%$, but were inferior in such indicators as the carcass output by $1.5 \%$ and speck thickness over 6-7 thoracic vertebrae - by $14.06 \%$.

In the experimental group, the carcass yield and pigs' fatness were higher than in the control by $1.5 \%$ and $0.46 \mathrm{~cm}$. Chemical analysis of rib eye meat showed that in the control group carcass meat, the protein content was higher by $0.7 \%(19.5-18.8)$, fat content - by $0,4 \%(15.9-15.5)$, ash content - by $0.9 \%(12.9-12.0)$, with a content decrease in rib eye by $2.0 \%$ of water content (51.7 - 53.7).

Economic efficiency calculations showed that the use of "Alma" PVMA developed by us (prepared in local conditions) being fed as part of a full-fledged combined fodder was not less economically effective compared to PVMA (protein concentrate) by "Provimi" (table 3).

Table 3. Economic efficiency of various combined fodder application.

\begin{tabular}{|l|c|c|}
\hline \multicolumn{1}{|c|}{ Indicator } & \multicolumn{2}{|c|}{ Group } \\
\cline { 2 - 3 } & control & experimental \\
\hline Cost of 1 kg of feed, rub. & 14.23 & 12.29 \\
\hline $\begin{array}{l}\text { Cost of combined fodder consumed per 1 head for the } \\
\text { accounting period, rub. }\end{array}$ & 2230.41 & 2149.76 \\
\hline Obtained gain in 54 days of accounting period per 1 head, rub. & 33.74 & 33.02 \\
\hline Cost of combined fodder consumed per 1 kg of gain, rub. & 66.11 & 65.10 \\
\hline
\end{tabular}

Due to the reduced cost of the experimental feed $(-1.94$ per $1 \mathrm{~kg}) 1.00 \mathrm{rub}$. was saved on each gain $\mathrm{kg}(66.11-65.10)$ in the experimental group spent per $1 \mathrm{~kg}$ gain

The results of the experiment are considered positive, since with a slight decrease in the pigs' growth rate in the experimental group the cost was 0.23 rub. lower than in the control group. The results of this experiment can be successfully used in young pigs' fattening on pig farms and complexes in Northern Trans-Urals with the help of PVMA of our development at "Tyumen grain-producing integrated works" and the cultivation of local grain crops.

To confirm the efficiency of using local raw materials to produce PVMA "Gloria", research was conducted on young fattening pigs 
During the accounting period of experiment, animals of control group received full combined fodder with the introduction of PVMA "Provimi" in the amount of $10 \%$, animals of the experimental group received combined fodder with the introduction of $15 \%$ PVMA "Gloria" (OJSC "Bogdanovichesky feed mill").

Indicators of growth, pigs' development, consumption of combined fodder for live weight gains production in experimental groups for 78 days of the accounting period are shown in table 4.

Table 4. Pigs' productivity in groups.

\begin{tabular}{|l|c|c|}
\hline \multirow{2}{*}{ Indicator } & \multicolumn{2}{c|}{ Group } \\
\cline { 2 - 3 } & control & experimental \\
\hline Average daily gain for the accounting experimental period, g & 703 & 628 \\
\hline Including by months, g & & \\
\hline 10 & 728 & 625 \\
\hline 11 & 683 & 626 \\
\hline 12 & 521 & 631 \\
\hline Feed consumption per 1 kg of gain, kg & 4.5 & 4.7 \\
\hline Obtained gain in 78 days of accounting period per 1 head, kg & 54.83 & 48.96 \\
\hline Average daily fodder consumption, kg & 3.16 & 3.00 \\
\hline
\end{tabular}

From the data of table 4 it can be seen that when feeding the abovementioned fodder, the intensity of live weight gain was in favor of the control group (by $75 \mathrm{~g}$, or $10.7 \%$ ), which led to that this group received an additional $5.8 \mathrm{~kg}$ of gain over 78 days of the accounting period compared to the animals of the experimental group.

Calculation of the economic efficiency of various combined fodder use is shown in table 5 .

Table 5. Economic effectiveness of research results

\begin{tabular}{|l|l|l|}
\hline \multicolumn{1}{|c|}{ Indicator } & \multicolumn{2}{c|}{ Group } \\
\cline { 2 - 3 } & control & experimental \\
\hline Cost of 1 kg of feed, rub. & 4.16 & 2.59 \\
\hline Cost of combined fodder consumed by 1 head per day, rub. & 13.15 & 7.77 \\
\hline $\begin{array}{l}\text { Cost of combined fodder consumed per 1 head for the } \\
\text { accounting period, rub. }\end{array}$ & 1025.7 & 606.06 \\
\hline Obtained gain per head in 78 days of accounting period, kg & 54.83 & 48.96 \\
\hline Cost of combined fodder consumed per 1 kg of gain, rub. & 18.71 & 12.38 \\
\hline
\end{tabular}

Economic efficiency calculation of different fodder feeding to experimental groups showed that due to the reduced cost of experimental PVMA $(19,05 \mathrm{rub}$. per $1 \mathrm{~kg})$, the cost of the consumed combined fodder per $1 \mathrm{~kg}$ gain in the experimental group (with same other costs) was 6.33 rub. lower compared to the control group. Consequently, experimental fodder feeding led to a decrease in the cost of $1 \mathrm{~kg}$ of gain by the abovementioned amount when fattening young pigs.

\section{Conclusions}

Having conducted experimental studies, we came to conclusions that our formulation of PVMA "Alma" (LLC "Tyumen grain-producing integrated works") consisting of local grain crops allowed to reduce the fodder cost by 1.01 rub., although there was a slight decrease in gains during the fattening period, on average per $1 \mathrm{~kg}$ can be successfully used in young pigs' fattening on pig farms and complexes in Northern Trans-Urals. To confirm 
the efficiency of using local raw materials for the production of PVMA "Gloria" (OJSC "Bogdanovichesky feed mill"), research was conducted on young fattening pigs, which also allowed to reduce the cost of production by reducing the price of combined fodder by 1.57 rub. per kg.

\section{References}

1. N.I. Tatarkina Proceedings of Orenburg State Agrarian University, 3(77), 266 (2019)

2. A. P. Poryvaeva, I. M. Donnik, A.G. Isaeva, International Transaction Journal Of Engineering Management \& Applied Sciences \& Technologies, 1(19), 10A19L, (2019)

3. O.V. Kovaleva, F.Kh. Betlyaeva Issues of regulatory and legal regulation in veterinary medicine, 1, 308 (2020)

4. A. Sharipova, D. Khaziev, S. Kanareikina, Z. Yessimbekov, O. Bykova, Annual Research and Review in Biology, 21(6), ARRB.38429 (2017)

5. I. Donnik, O. Bykova; A. Krivonogova, International transaction journal of engineering management \& applied sciences \& technologies, 10(2), 203-209 (2019)

6. Stolbova, O. A. Indo-american Journal of Pharmaceutical Sciences, 6(6), 13337 (2019)

7. O.K. Sintiurev, L.A. Glazunova, A.V. Plakhotnik, IIOAB JOURNAL, 11(3), 1 (2020)

8. E.I. Anisimova, A.G. Koshchaev, A.A. Nesterenko, T.M. Shuvaeva, T.V. Kalashnikova, International Journal of Pharmaceutical Research, 10(4), 604-610 (2018) 